\title{
The last portrait of Willem Einthoven: newly discovered links between Sir Thomas Lewis and Alexander Samojloff
}

\author{
Dennis M Krikler, Arthur Hollman
}

The discovery of previously unknown personal links between scientists is of particular interest when political and military crises interfere with normal contacts, and subsequently shows the value of their contributions. During both world wars knowledge of what was happening in occupied areas or in enemy countries was blocked. But there were occasional gaps. Lepeschkin, working in Bad Nauheim in Germany in 1942, was able to cite up to date references from the British Heart Journal in his textbook of electrocardiography ${ }^{1}$; presumably he received the journal through Switzerland. Far more commonly delays in communication meant that the work of individuals went unrecognised, so that in occupied France in 1943 Lenègre and Maurice developed diagnostic cardiac catheterisation without knowing of Cournand's slightly earlier studies ${ }^{2}$ in the United States.

Alexander Filipovich Samojloff was a Russian pioneer of electrocardiography ${ }^{3}$ who took up the subject in 1904 after visiting Willem Einthoven to learn of his work with his newly developed string galvanometer. ${ }^{4}$ Few clues link Samojloff with other workers in electrocardiography apart from his description of a visit to Boston in 1929 when he addressed Paul Dudley White's postgraduate students." This was his third visit to Boston; he went there to see his twin sons who had emigrated from Russia during the civil war that followed the Bolshevik revolution. During the second of these visits White, in a note to his mother, described Samojloff as being “. . . a physiologist much interested in electrocardiography, in which he is one of the world's authorities."

\footnotetext{
Cardiovascular

Division, Royal

Postgraduate Medical

School, London

D M Krikler

Department of

Medicine, University

College and Middlesex

School of Medicine,

London

A Hollman

Correspondence to

Dr Dennis M Krikler,

Cardiovascular Division,

Cardiovascular Division,
Royal Postgraduate Medical

Rchool, 150 Ducane Road,

London W12 0NN.
}

\section{Links with Einthoven}

During his 1929 visit Samojloff gave a talk on Einthoven ${ }^{5}$ and told his audience about a photograph of Einthoven that he thought to be a particularly good likeness; it was given to him by his mentor during Samojloff's last visit to Leiden in 1927, shortly before Einthoven's death. Samojloff offered to send a copy to the Massachusetts General Hospital on his return to Russia but it cannot be found there or among White's papers (Oglesby Paul, per- sonal communication); nor is there a copy in Samojloff's archive (Anna Samojloff, personal communication).

In 1989, after the death at the age of 99 of Lady Lewis- 44 years after that of her husband-one of us ( $\mathrm{AH})$ was asked to examine her collection of photographs and found a portrait of Einthoven (fig 1). The inscription above the head reads "Seinem lieben Freunde Herrn Prof A Samojloff." (His dear friend ...). The clear signature at the bottom of the picture is "W Einthoven".

How well did Lewis and Samojloff know each other? Did Lewis know that by the second half of 1908 the University of Kazan already had a Cambridge string galvanometer,

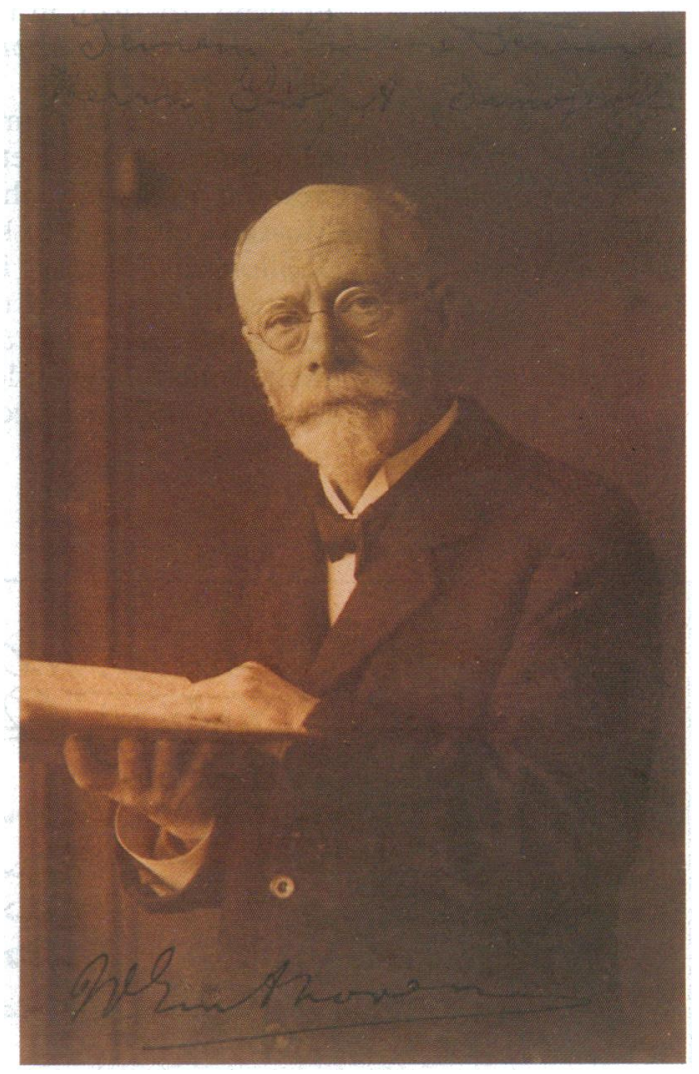

Figure 1 Photograph of Willem Einthoven, signed by himself and inscribed to Samojloff, taken in 1926 or 1927. 


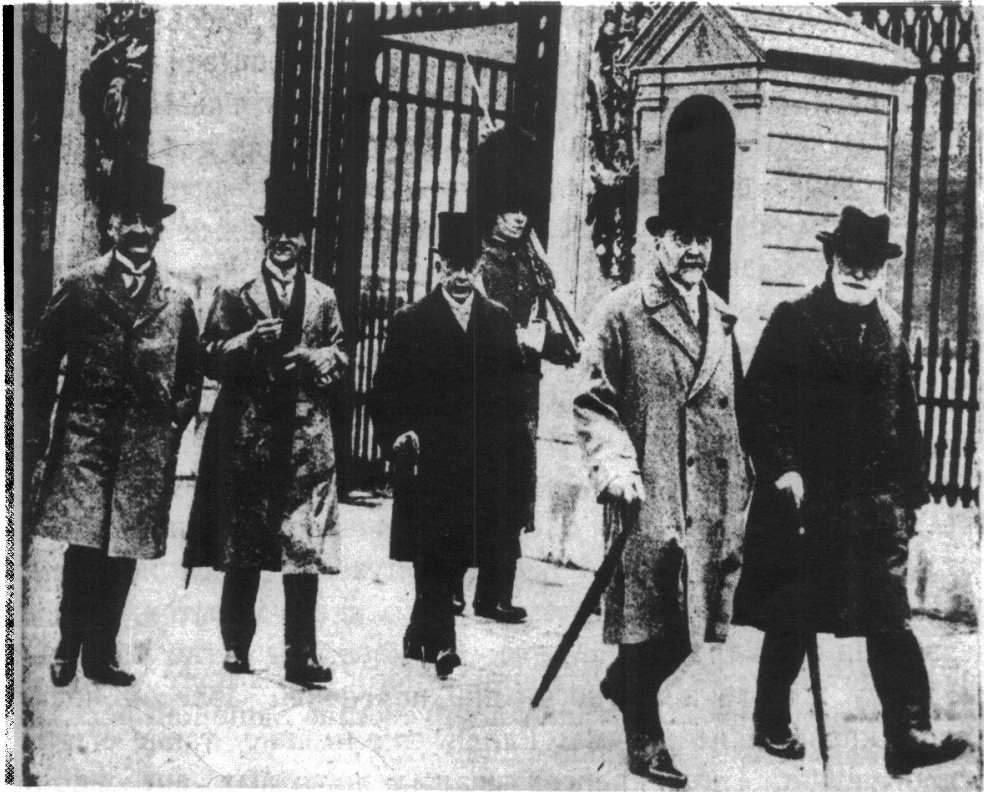

Figure 2 Photograph of Professors I P Pavlov (extreme right) and A F Samojloff in formal dress in front of Buckingham Palace (reproduced by permission from Krikler ${ }^{3}$ ).
Dear Dr Lewis,

Kasan, 1928 x, 22

I read your article about the late Prof. W. Einthoven in the 'Heart' and in Proc. of the R.

$S$. In both journals there are given the photos of Einthoven. The portrait however does not seem to be fully true to nature and does not give characteristic traits of the face of the man whom we all so deeply estimed. Some months for his death the late Einthoven presented me with his photograph which I consider to be excellent in every point. If you are interested in having a copy of it I will be happy to send you one.

With great pleasure I remember the nice time I spent in London during the Harvey Celebration.

With kind regards and best wishes,

Your truly

Prof. A. Samojloff

Kasan U.S.S.R.

University

Laboratory of Physiology the sixth that the manufacturers made? Earlier in 1908 Lewis had ordered an instrument from the Edelmann company of Munich, ${ }^{8}$ but he took his first published electrocardiogram with a string galvanometer belonging to A D Waller in November 1908,' so perhaps his Edelmann instrument was slow in arriving. It is curious that Lewis had turned to Germany for his apparatus while his Russian contemporary bought one from England. In 1925, in the third edition of The Mechanism and Graphic Registration of the Heart Beat ${ }^{10}$ Lewis cited nine works by Samojloff, one of them three times, but they had probably not yet met. Samojloff, still working in Kazan, though also teaching in Moscow, managed to keep abreast of Lewis's publications. These included the obituary notices of Einthoven that appeared in Heart and in the Proceedings of the Royal Society that elicited the following letter from Samojloff to Lewis (copied uncorrected from the original):

\section{Samojloff and Lewis}

The visit to London that Samojloff mentioned was for the tercentenary celebration in 1928 by the Royal College of Physicians of the publication of De Motu Cordis. The celebration started on 14 May with a reception by King George $\mathrm{V}$ at Buckingham Palace in front of which Samojloff was photographed with Pavlov (fig 2). ${ }^{311}$ The next two days were occupied by scientific sessions at University College London which included the film which Lewis and Henry Dale had made of Harvey's experiments, and a demonstration of the blood vessels of the human skin by Lewis, R T Grant, and K E Harris. Illness prevented Lewis from attending these sessions and the College's Registrar, Dr Raymond Crawford, wrote to tell him of the acclaim with which the film was received. So Samojloff would not have met Lewis then nor at the Guildhall banquet on 16 May where they were both allocated seats. During the commemoration the college conferred an honorary fellowship

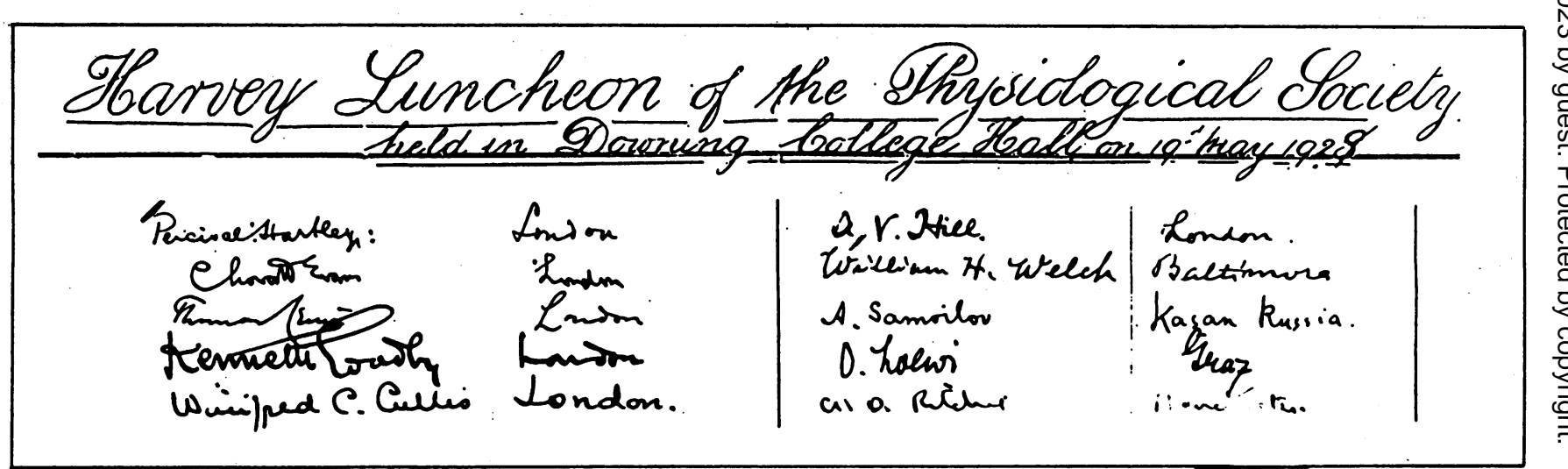

Figure 3 Extracts from list of signatures of those who attended the Physiological Society luncheon to commemorate De Motu Cordis, rearranged to show the autographs of Lewis and Samojloff side by side in the third line (reproduced with the permission of the Physiological Society). 


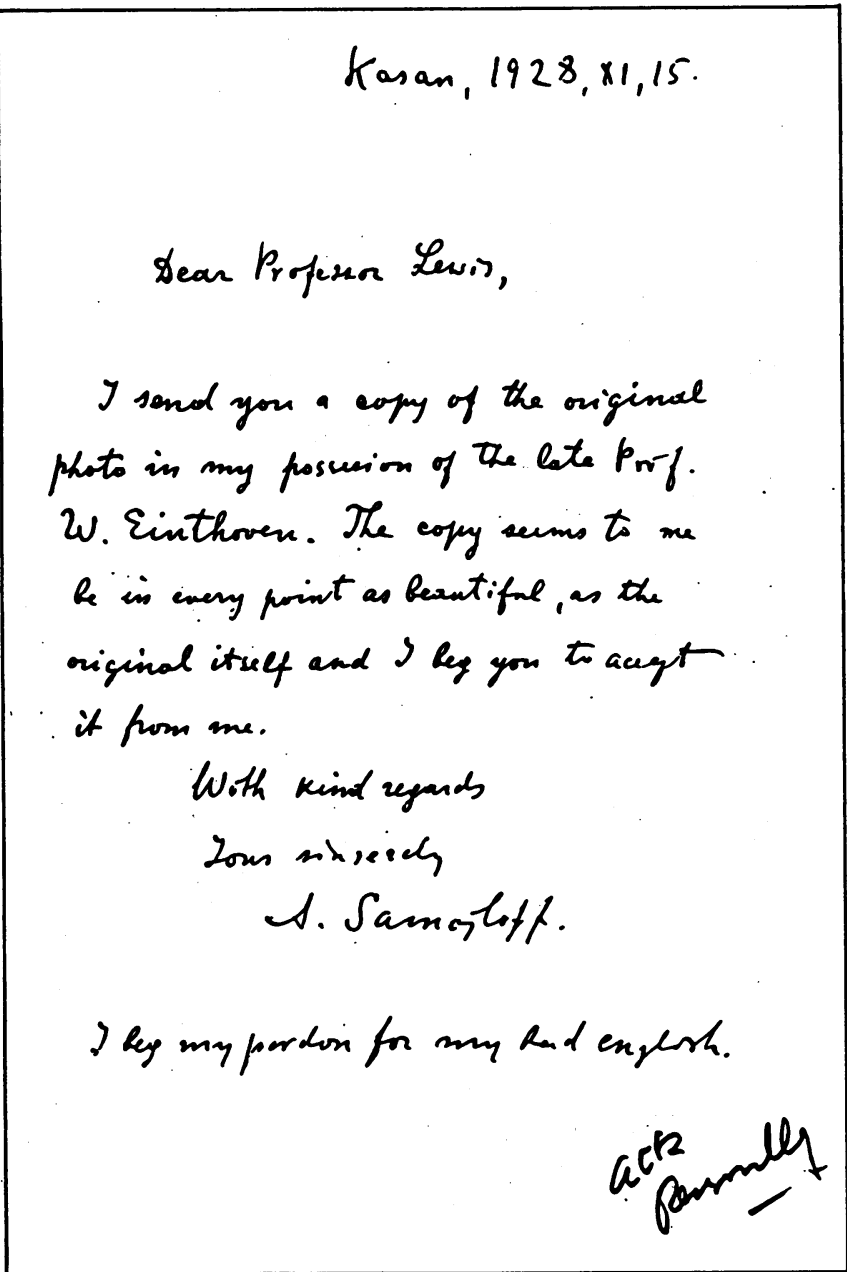

Figure 4 Copy of a handwritten note from Samojloff to Lewis, Kazan, 15 November 1928, that accompanied the photograph of Einthoven; note Lewis's handwritten comment "ack personally" (Contemporary Medical Archives Centre, PP/LEW/A.1/660).

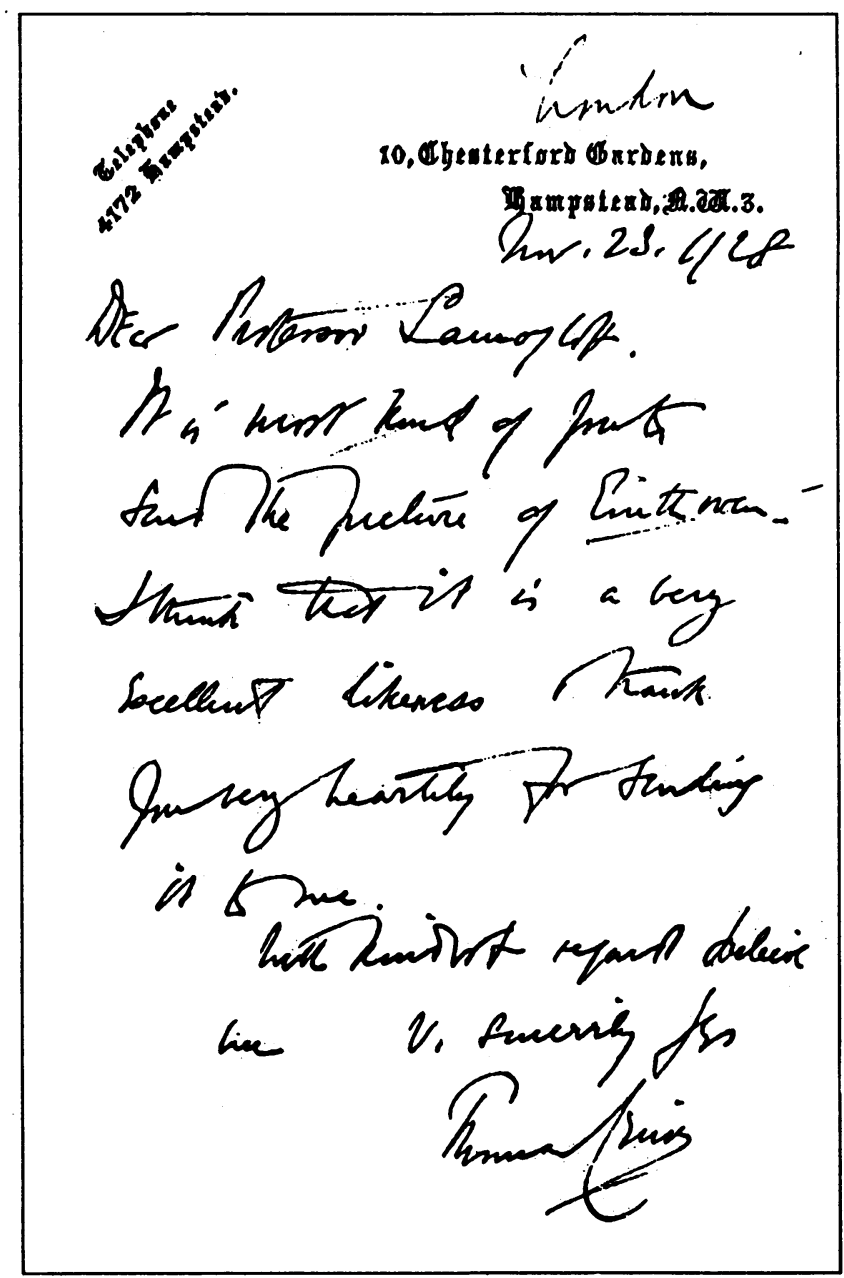

Figure 5 Copy of a handwritten note from Lewis to Samojloff, 23 November 1928, acknowledging receipt of the photograph of Einthoven: "It is most kind of you to send the picture of Einthoven. I think that it is a very excellent likeness and thank you very heartily for sending it to me. With kindest regards believe me v. sincerely yrs Thomas Lewis." on the other principal Russian visitor, I P Pavlov, and also on K F Wenckebach of Vienna.

The Physiological Society commemorated the occasion with a meeting at Downing College, Cambridge, on 19 May where Lewis and Samojloff did after all have the opportunity of seeing each other-both their signatures appear on the list of those attending the Harvey luncheon that day (fig 3). Lewis was elected a member of the Society on 23 January 1904, early in his career; indeed, before he had qualified in medicine.

Samojloff's first, handwritten, letter is in the Contemporary Medical Archives Centre at the Wellcome Institute for the History of Medicine (PP/LEW/A.1/659) and is annotated "Ack personally" in Lewis's handwriting, so there is no copy of his reply. Within three weeks Samojloff had responded (fig 4) and had sent the photograph (fig 1).

Lewis and Einthoven were close friends and regular correspondents ${ }^{12}$; the personal links between Einthoven and Samojloff were even closer and indeed of longer duration. ${ }^{3}$ Though Samojloff only established personal contact with Lewis towards the end of his life, he clearly had kept in touch with Lewis's work, despite all the problems of the unsettled times in post-revolutionary Russia. Unfortunately, there is no mention of this correspondence in the volume of collected works of Samojloff published by the USSR Academy of Science on the centenary of his birth ${ }^{13}$; while this contains an account of some of his international contacts, correspondence is limited to several letters from Russian colleagues. There is nothing to or from Einthoven, with whom he had exchanged letters for more than twenty years-the Einthoven archive in Leiden contains about 70 letters from Samojloff to Einthoven, some of them supplemented by a short summary of Einthoven's reply (H A Snellen, 1990, personal communication). Nor, alas, is there anything to or from Lewis.

Just after this article was submitted, Nora Andreevna Grigoryan, the editor of Samojloff's collected works, ${ }^{13}$ found several letters from Lewis among Samojloff's personal papers. In January 1910 Lewis's secretary thanked Samojloff for "his kindness in sending reprints of his interesting and valuable papers." Lewis followed this up with a personal letter in his own handwriting on 20 April 1910, in which he wrote "Dr Lewis 
would be glad if Professor Samojloff would send him reprints of his published works on the electrocardiogram." In addition to acknowledgments of reprints over the years, in a handwritten letter Lewis (15 August 1922) commented on a paper on atrial flutter by Samojloff, of which he had received a reprint, and discussed various interpretations of the cycles. But the most interesting letter is that sent in 1928, in which Lewis thanked Samojloff for the picture of Einthoven, which he also admired (fig 5 ).

The letters from Samojloff are reproduced with the permission of his daughter Anna Samojloff of Moscow and through the courtesy of the Trustees of the Wellcome Trust, whom we also thank for permission to mention the letter from Raymond Crawford to Lewis. We thank Professor R A Chapman, secretary of the Physiological Society, for permission to use secretary of the Physiological Society, for permission to use material from their archives and $\mathrm{Mr} D \mathrm{H}$ Steven, honorary archivist, for the list of those attending the Society's Harvey librarian, Royal College of Physicians, kindly provided details of the College celebration.

1 Lepeschkin E. Das Elektrokardiogramm. Ein Handbuch fur Theorie und Praxis. Dresden and Leipzig: Verlag von Theodor Steinkopff, 1942.
2 Maurice $P$. Jean Lenègre et les potentiels électriques endocavitaires. In: Snellen HA, Dunning AJ, Arntzenius AC, eds. History and perspectives of cardiology. Catheterization, angiography, surgery and concepts of Catheterization, angiography, surgery and concepts of
circular control. Leiden: Leiden University Press, 1981: 53-7.

3 Krikler DM. The search for Samojloff: a Russian physiologist in times of change. Br Med J 1987;295:1624-7.

4 Einthoven W. Die galvanometrische Registrirung des menschlichen Elektrokardiogramms, zugleich eine Beurtheilung der Anwendung des Capillär-Elektrometers in der Physiologie. Pflugers Arch ges Physiol 1903;99: 472-80

5 Samojloff A. Reminiscences of the late Professor Willem Einthoven. Am Heart J 1930;5:685-99.

6 Krikler DM. Alexander Filipovich Samojloff and Paul Dudley White: electrocardiography and a RussianAmett J. The origins of the electrocardiograph as a clinical instrument. Med Hist 1985;suppl 5:53-76.

instrument. Med Hist 1985;suppl 5:53-76.
8 Burchell HB. A centennial note on Waller and the first human electrocardiogram. Am J Cardiol 1987;59:979-83.

9 Lewis T, Macnalty AS. A note on the simultaneous occurrence of sinus and ventricular rhythms in man. $J$ occurrence of sinus and
Physiol 1908;37:445-58.

10 Lewis T. The mechanism and graphic registration of the heart beat. 3rd ed. London: Shaw and Sons, 1925.

11 Cooke AM. A history of the Royal College of Physicians of London. Volume 3. London: Oxford University Press, 1972:1050.

12 Snellen HA. Two pioneers of electrocardiography. The correspondence between Einthoven and Lewis from 1908-19

13 Grigoryan NA. A F Samojloff. Selected works [in Russian]. Moscow: "Nauka", 1967. 